\title{
INTEGRASI PADI MERAH DAN TERNAK LEMBU MENDUKUNG KETAHANAN PANGAN DI TAPANULI SELATAN
}

\author{
Ameilia Zuliyanti Siregar ${ }^{1 *}$, Tulus, ${ }^{2}$ Yunilas $^{3}$ \\ ${ }^{1}$ Departemen Agroteknologi, Fakultas Pertanian, Universitas Sumatera Utara, Medan, Indonesia \\ ${ }^{2}$ Departemen Komputer, Fakultas MIPA, Universitas Sumatera Utara, Medan, Indonesia \\ 3Departemen Peternakan, Fakultas Pertanian, Universitas Sumatera Utara,Medan, Indonesia \\ *Penulis Korespodensi : Ameilia@usu.ac.id, ameiliazuliyanti@gmail.com
}

\begin{abstract}
Abstrak
Sumatera Utara sebagai sumber penghasil beras teridentifikasi kekurangan energi protein, dapat dikendalikan melalui konsumsi beras merah dan daging lembu. Di Sumatera Utara, lahan tanam beras merah diidentifikasi pada 7 Kabupaten, diantaranya adalah Tapanuli Selatan. Penanaman beras merah spesifik lokal terdapat di Desa Tanjung Dolok, Kec.Marancar, Kab.Tapsel, manakala pengelolaan ternak lembu sebagai sumber protein hewani yang potensial di Desa Sijungkang, Kec. Angkola Timur, Kab. Tapsel, Sumatera Utara. Oleh sebab itu, sangat penting dilakukan kegiatan Pengabdian Pengembangan Desa Mitra (PPDM) selama 3 tahun dengan menganalisis kedua faktor (internal dan eksternal), strategi penting, konservasi, pengelolaan pertanian beras merah dan ternak lembu lokal terpadu mendukung ekowisata sebagai upaya menumbuhkembangkan kegiatan ekonomi kreatif. Sistem tani ternak (tanter), salah satu alternatif pemecahan masalah strategis dan efektif dengan keuntungan ekonomi, sosial dan ekologi. Induksi pengetahuan tentang pola tanam tepat guna, Pengendalian Hama Terpadu menggunakan Sweep Net (perangkap jaring), Yellow Sticky Trap (perangkap pelikat kuning), pestisida nabati, dan pakan prebiotik bagi ternak lembu diharapkan meningkatkan produktivitas hasil pertanian dan peternakan. Tanter sebagai sumber pangan protein produktif diharapkan mendukung peningkatan ketahanan pangan di Sumatera Utara.
\end{abstract}

Kata kunci: Integrasi, Beras Merah, Ternak Lembu, Ketahanan Pangan, Sumatera Utara.

\begin{abstract}
North Sumatra, as a source of rice production has identified a lack of protein energy, which can be controlled by consumption of red-rice and cattle. In North Sumatra, planting areas for red rice were identified in 7 districts, such as South Tapanuli. Local planting of red rice is found in Tanjung Dolok Village, Marancar Subdistrict, Tapel Regency, when the management of cattle as a potential source of animal protein is in Sijungkang Village, Kec. East Angkola, Kab. Tapsel, North Sumatra. Meanwhile, it is focused to determined the Village Partnership Development Service (VPDS) activity for 3 years by analyzing both of factors (internal and external), importance strategies, conservation, integrated management of red rice agriculture and local cattle to support ecotourism as a work to develop of economy creative. The livestock farming system (tanter), is an alternative solution to strategic and effective problems with economic and ecologicaly. Knowledge introduced used appropriate cropping patterns, Integrated Pest Management (IPM) using Yellow Sticky Trap (YST), Sweep Net (SN), vegetable pesticides, and the manufacture of prebiotic feed for cattle are expected to increase the productivity of agricultural and livestock products. Tanter as productive alternative food was expected support increased food security in North Sumatra
\end{abstract}

Key words:, Integration Red Rice, Cattle Livestock, Food Security, North of Sumatra. 


\section{Pendahuluan \\ 1. PENDAHULUAN}

Sumatera Utara terdeteksi atas terbatasnya asupan protein, vitamin, yodium serta anemia. Ketiga masalah diatas dapat diatasi melalui penggunaan beras merah. Beras merah (Oryza nivara), sumber makanan yang memiliki zat-zat gizi dapat memberikan manfaat bagi kesehatan [Manzi dkk., 2007]. Menurut Juniawati dkk. (2015), terdapat vitamin, asam amino, serat pangan, prebiotik, probiotik, kolin, lesitin, inositol, karnitin, skualen, isoflavon, fitosterol, fitostanol, polifeno,l gula, mineral, alkohol, asam lemak tidak jenuh sebagai pangan yang menyehatkan.

Sebanyak 7 kabupaten di Sumatera Utara sentra penghasil beras merah, yaitu di Serdang Bedagai, Simalungun, Karo, Dairi, Nias Langkat, dan Tapsel. Tapsel terdiri dari 12 Kecamatan, yaitu dari Padang Sidempuan, Sipirok, Saipar Dolok Hole, Arse, Aek Bila, Angkola Barat, Angkola Timur, Angkola Selatan, Batangtoru, Batang Angkola, Sayur Matinggi dan Marancar. Kecamatan Marancar, khususnya di Desa Tanjung Dolok masih ditemukan penanaman beras merah spesifik lokal sedangkan pengelolaan ternak lembu potensial di Desa Sijungkang, Kec. Angkola Timur, Sumatera Utara (lihat Gambar 1).

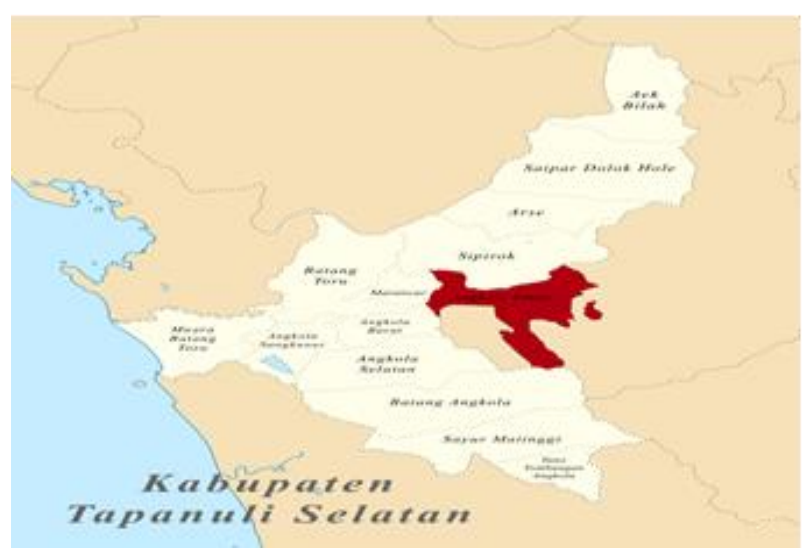

Gambar 1. Peta lokasi pengabdian Multi Tahun 2020 di Kec.Marancar dan Kec. Angkola Timur, Tapsel

Dinas Pertanian Kabupaten Tapanuli Selatan, Sumatera Utara disampaikan "sebanyak produksi beras sepanjang musim tanam Tahun 2016 sebanyak 181 ton lebih, meningkat dibandingkan produksi tanam 2015 sebanyak 169 ton lebih", Kadis Pertanian Tapsel, Ir Bismark Siregar melalui Sekretaris Ir Derianto kepada Antara, di Sipirok. Sementara jumlah kebutuhan beras Tapsel 2016 sebanyak 134 ton lebih, dan untuk kebutuhan pangan 39 ton lebih, sehingga Tapsel 2016 surplus beras sebanyak 84 ton lebih atau setara $67,89 \%$. Produksi padi sebanyak itu dihasilkan Tapsel dari luas baku sawah tahun 2016 seluas $17.170 \mathrm{Ha}$, berkurang dibanding tahun 2015 dimana luas baku sawah seluas
17.847 Ha. Pengurangan luas baku sawah seluas $677 \mathrm{Ha}$ tersebut tersebut diprediksikan akibat adanya alih fungsi lahan oleh masyarakat.

Namun, pada tahun 2017, Dinas Pertanian Tapsel akan berusaha meningkatkan produktifitas pertanian sawah dengan target Indeks Pertanaman 2.5 tanam komoditi padi diatas lahan seluas 48.046 Hektar. Peningkatannya dengan cara intensifikasi melalui peningkatan IP (indeks pertanaman) itu dengan merehabilitasi jaringan irigasi desa, penggunaan bibit unggul (label biru) pengunaan metode pertanaman dengan sistem Jarwo (jajar legowo), metode SRI (Sistem Rice Intensification), hazton dan lainnya, pupuk organik tepat waktu, tepat sasaran, tepat dosis, dan memaksimalkan alat-alat mesin pertanian [Manzi dkk., 2007]. Ditambah irigasi teknis, jalan usaha tani (untuk mobilisasi angkutan hasil pertanian), rumah tunda jual (mengurangi tengkulak), update informasi pasar pertanian ditingkatkan [Juniawati dkk., 2015].

Disamping itu, dukungan PPL (Petugas Penyuluh Lapangan) yang handal akan diintensifkan petani diajak praktek usaha tani yang baik/benar (good agricultural practices)," ujar Derianto didampingi Kabid tanaman pangan Iswal Parnigotan dan Kabid Prasarana dan sarana Mhd.Taufik Batubara. Sslanjutnya pembangunan dan pegembangan Demplot (Demonstrasi Plot) dan Demfarm (Demonstrasi Farming). Manakala cara ekstensifikasi dilakukan dengan pembuatan atau pengembangan cetak sawah baru.

Dalam pengembangan pertaniannya Dinas Pertanian Tapsel masih menggunakan varietas Mekongga, Inpari 29, 30,31,32 dan IPB 30 S serta padi merah spesifik lokal. Dalam menjaga kualitas dan kemurnian berasnya, Dinas Pertanian Tapsel melaksanakan penyuluhan bagi kelompok tani dan bantuan gilingan padi berstandar SNI ke kelompokkelompok tani. Sedang untuk pemasaran produksi beras Tapsel di wilayah Provinsi Sumut, seperti ke Kab Mandailing Natal, Tapanuli Tengah, dan Labuhan Batu Raya. Diproduksi dari sebagain besar wilayah Kec di Tapsel seperti Tantom Angkola, Sayur Matinggi, Batang Angkola, Angkola Timur, Marancar, Sipirok, dan Batangtoru [Kadir dkk., 2007].

Luas lahan padi ladang atau gogo di Tapsel masih kalah jauh dibanding padi sawah. Untuk meningkatkan produksi padi gogo, Dinas Pertanian Kab Tapsel dan Balai Pengkajian Teknologi Pertanian Sumut mulai melakukan penanaman padi gogo beras merah varietas Inpago 7, Sigembiri dan Inpari. Potensi produksi padi Inpago 7, bisa mencapai angka 4 - 5 ton per hektar, lebih lebih tinggi daripada padi gogo lainnya yang mencapai 3 ton per hektar [John, 2018]. Pengunaan pupuk an-organik (urea, TSP, $\mathrm{KCl}$ ) yang semakin intensif dan keterbatasan luas lahan mengakibatkan eksploitasi lahan secara berkesinambungna. Hal ini 


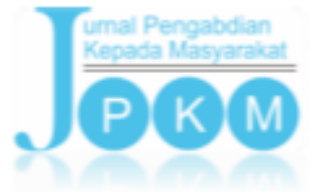

mempengaruhi pertumbuhan tanaman, khusunya padi di lahan sawah. Disamping itu, adanya konversi lahan pertanian ke non pertanian dapat menurunkan produk padi. Oleh karena itu potensi lahan gogo yang ada perlu dikembangkan dan mencari sumber alternatif lainnya,seperti pemanfaatan lahan kelapa sawit, lahan tanaman karet dan lainnya [Suriadikarta dan Sutriadi, 2007].

Galur BP1924-1e-5-2 dengan nama varietas Aek Sibundong telah diperkenalkan ke masyarakat di 7 provinsi (Sumut, Jabar, Jateng, Jatim, Bali, Sulsel, dan NTB) oleh Balai Besar Pengabdian Tanaman Padi, Badan Pengabdian dan Pengembangan Pertanian. Dari data responden dan evaluasi yang dilakukan, masyarakat di desa umumnya lebih menyukai rasa nasi merah dibanding responden penduduk di kota, kecuali responden di propinsi Jatim dan Bali. Selanjutnya, di Bali, NTB, dan Sumut memiliki tingkat pengetahuan dan mengonsumsi beras merah lebih banyak dibanding propinsi lainnya.

Selanjutnya pada padi gogo terdeteksi hama utama, diantaranya adalah wereng, penggerek batang padi, walang sangit, orong-orong dan keong mas. Akibat sistem irigasi di Indonesia mempengaruhi distribusi keong mas yang mengikuti aliran air di sawah tergenang [Riyanto, 2004; Nurhayati dkk, 2012]. Keong mas merupakan hewan yang bersifat herbivora dan makannya sangat rakus sehingga dikeluarkan beberapa aturan yang membatasi bahkan melarang pembudidayaan dan peredaran keong mas [Riani, 2011]. Potensi pemanfaaatan hama keong mas sebagai pupuk tanaman padi masih jarang dilakukan. Oleh karena itu, disamping invetarisasi jenis varietas padi merah maka pengembangan teknologi tepat guna memanfaatkan hama keong mas sebagai pupuk hayati produktif bagi peningkatan produktivitas tanaman padi merah perlu dilakukan.

Di Indonesia, usaha ternak lembu, kambing dan lembu berkembang sebagai usaha sampingan yang bertujuan sebagai investasi. Akibatnya, manajemen pemeliharaan dan perawatan ternak dilakukan secara konvensional. Disamping itu, diasumsikan kendala utama petani belum memadukan usaha tani-ternak karena tidak tersedianya pakan secara memadai terutama pada musim kemarau [Muzani dkk.,2004]. Menurut Ilham dkk. (2001), petani terpaksa menjual ternak dengan harga relatif murah untuk mendukung keperluan harian.

Oleh karena itu, diperlukan sistem integrasi taniternak. Pemanfaatan limbah tanaman seperti jerami padi, limbah jagung, limbah kacang-kacang, dan limbah pertanian lainnya akan menjadi sumber pakan ternak. Saat musim kemarau, limbah pertanian dapat menyediakan pakan sebesar 33,3 persen dari total rumputatau hijauan yang dibutuhkan [Kariyasa, 2003].
Nilai lebih pemanfaatan limbah adalah mampu meningkatan "ketahanan pakan" di musim kemarau, dan dapat menghemat tenaga kerja untuk mencari rumput, sehingga memberi peluang petani atau peternak lebih diuntungkan.

Pembuatan pakan ternak serta bahan kompos padat dan cair dapat dilakukan. Disamping menjaga dan mengawasi kesehatan reproduksi hewan ternak, juga dianggap penting membuat kandang inseminasi buatan dalam membentuk pola pengelolaan ternak lembu sebagai sumber protein hewani yang potensial di Desa Sijungkang, Kec. Angkola Timur, Sumatera Utara.

Oleh sebab itu, sangat penting dan bernilai strategis dilakukan kegiatan Pengabdian Pengembangan Desa Mitra untuk mencapai tujuan khusus menggunakan 3 Mitra, yaitu: Taberah, Tani Padi merah; Tersapu, Ternak Lembu Unggul dan Terikmas, Tani Ternak Lokal selama 3 tahun, meliputi kegiatan: 1 . Inventarisasi varietas padi merah dan lembu spesifik lokal; 2. Menganalisis faktor-faktor internal, eksternal, strategi pengembangan dan konservasi beras merah organik dan ternak lembu dan pemberdayaan ekonomi lokal melalui budaya/kearifan lokal; serta 3. Pengelolaan pertanian dan peternakan terpadu berbasiskan masyarakat berupa tani-ternak (tanter) dan ekowisata sebagai upaya menumbuh kembangkan kegiatan ekonomi kreatif. Sistem tanter, salah satu alternatif pemecahan masalah yang sangat strategis dan efektif dengan keuntungan ekonomi, sosial dan ekologi.

Tujuan umum program PENGABDIAN MULTI TAHUN 2020 dengan introduksi konsep ketahanan pangan kepada mitra adalah alternatif pemanfaatan lahan padi merah dan pemeliharaan lembu lokal dalam mengembangkan konsep kelestarian lingkungan, melalui kegiatan berkelanjutan dalam bentuk edukasi, pengabdian ilmiah, dan eduwisata. Induksi pengetahuan tentang pola tanam tepat guna, Pengendalian Hama Terpadu (PHT) dan Pemanfaatan keong mas sebagai pupuk produktif, disertai penambahan wawasan tentang pemeliharaan lembu lokal berkualitas, pembuatan pakan probiotik dan desain kandang inseminasi buatan diharapkan meningkatkan produktivitas hasil pertanian dan peternakan. Tanter sebagai sumber pangan protein produktif mempunyai peran sangat strategis dalam rangka peningkatan ketahanan pangan di Sumatera Utara. Program PENGABDIAN MULTI TAHUN 2020 berbasiskan pengetahuan, pengabdian dan sinergitas dengan masyarakat untuk mencapai tujuan khusus mewujudkan Desa Tanjung Dolok dan Desa Sijungkang sebagai model desa mitra unggulan dengan capaian peningkatan komoditas pangan dan ternak mendukung kebutuhan masyarakat, pembangunan desa dan ketahanan pangan nasional.

\section{Urgensi Permasalahan Prioritas}


Masa sekarang ini terdeteksi 54 varietas lokal padi merah hasil eksplorasi dan koleksi di Bank Gen Balai Besar Pengabdian dan Pengembangan Bioteknologi dan Sumberdaya Genetik Pertanian. Salah satunya diasumsikan adalah padi merah spesifik lokal Siredep-4245 [BB Biogen 2015] yang belum teridentifikasi penyebarannya di Tapsel. Gambar 2 dan Gambar 3 dibawah ini menunjukkan jenis padi merah yang sering ditanam di Tapsel, diantaranya adalah Kasumbo, Silotik (daerah asal Sipirok), Inpari dan Mekongga.

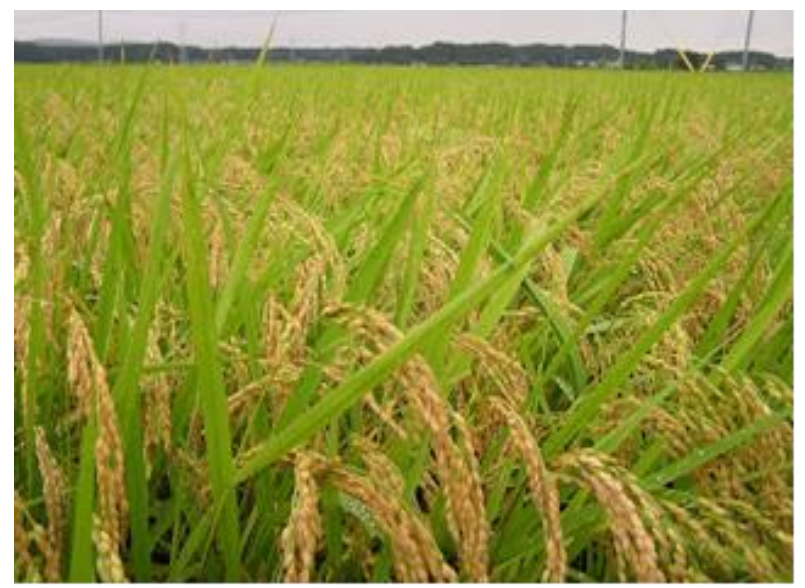

Gambar 2. Inpari 29 (Sumber: Internet, 2018)

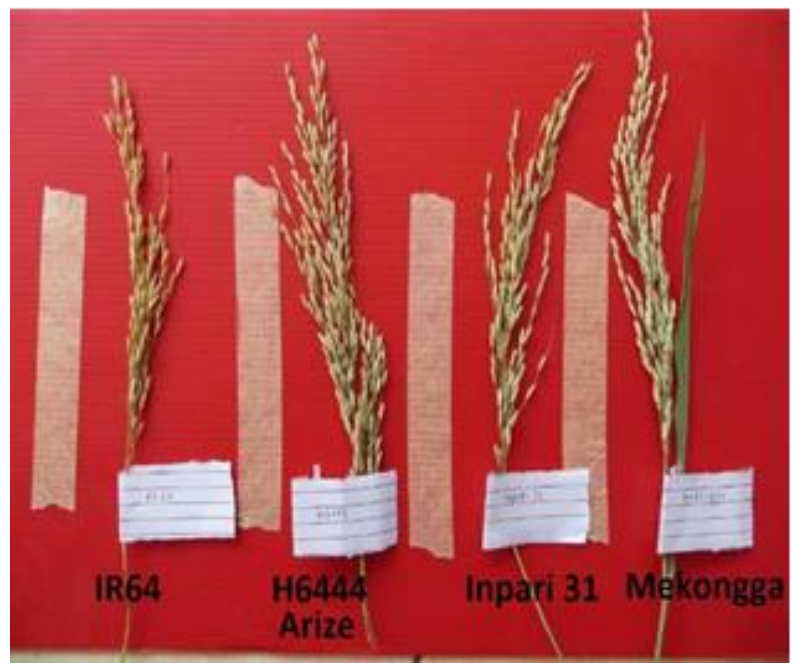

Gambar 3. Variasi padi merah (Sumber: Internet, 2018)

Menurut Haryanto (2002), Sistem Integrasi PadiTernak (SIPT) merupakan salah satu alternatif meningkatkan produktivitas padi, daging, susu, serta meningkatkan kesejahteraan petani. Badan Litbang Pertanian meneliti dan mengkaji Sistem Integrasi PadiTernak (SIPT) menggunakan pendekatan Zero Waste, dengan mengoptimalkan pemanfaatan sumberdaya lokal ( jerami sebagai pakan ternak dan kotoran ternak lembu sebagai pupuk organik) (Dirjen Bina Produksi Peternakan, 2002) Terdapat tiga komponen teknologi SIPT yaitu (a). Teknologi budidaya padi, (b).Teknologi budidaya ternak, dan (c) Teknologi pengolahan jerami dan kompos. Ketiga komponen teknologi dapat diintegrasikan secara sinergis sehingga pengembangan SIPT disosialisasikan dalam kelembagaan, yaitu kepemilikan lahan sawah tetap ada dan kelompok ternak mengumpulkan jerami padi, pengadaan saprodi dan pemasaran hasil (Haryanto dkk., 2002). Program SIPT dikenal sejak 2002 dilokasi lahan sawah irigasi, dan petaninya memelihara ternak lembu. Kegiatan SIPT merupakan bagian dari aktivitas PTT (Pengelolaan Tanaman Terpadu), yang direalisasi secara awal dengan pengembangan pada lahan seluas 50 ha dengan 80 ekor ternak lembu untuk 2 kelompok petani, di 11 Provinsi serta di 20 kabupaten. Dari 20 kabupaten tersebut juga dialokasikan dana dalam bentuk BLM (Bantuan Langsung Masyarakat) mendukung pengadaan ternak lembu, bantuan kandang, pakan penguat, tempat pemrosesan jerami, tempat pemrosesan kompos dan bantuan vaksin serta obat-obatan.

Manakala lembu lokal sudah sangat sulit ditemukan di suatu lokasi peternakan. Pemerintahan Kab Tapsel mengembangkan jenis Lembu Brahman Cross, ternak asal Australia. Namun ketersediaan ternak tersebut masih diwilayah terbatas. Tahun Anggaran 2016 Brahman Cross baru berjumlah 1.750 ekor di datangkan untuk paket Sumatera I (Aceh, Sumatera Utara dan Riau). Gungun Gunawa bagian Direktorat Pembibitan dan Produksi Ternak dari Kementrian Pertanian Dirjend Peternakan dan Kesehatan Hewan (PKH) menyampaikan ke Antara, di Sipirok.

Untuk lembu indukan Brahman Cross apabila panen dapat mencapai bobot badan mencapai 300-350 kilogram per ekornya. "Lembu ini untuk pertama kali secara geografis sangat berpotensi di Sumut untuk dikembangkan," terang Gungun. "Ada dua Kelompok Tani (Koptan) di Tapsel diberi bantuan sebanyak 25 ekor lembu Brahman Cross," kata Gungun. Pertama Koptan Berdikari di Bandar Tarutung, Kec Angkola Sangkunur, dan Koptan Maju Bersama di Desa Marlelan, Kec Muara Batangtoru. Salah satu syarat paling penting untuk dapat bantuan ternak lembu adalah permohonan awal melalui on-line (E-Proposal) ke pihak kementrian. Persyaratan lainnya keadaan atau ketersediaan kandang memadai, adanya stok pakan, air, akses tranportasi yang saling mendukung (terintegrasi) tapi bantuan bukan dalam bentuk uang”.

Solusi terhadap permasalahan masyarakat/mitra Desa Tanjung Dolok, Kec. Marancar dan Desa Sijungkang, Kec.Angkola Timur dibahas dalam analisa SWOT (Strenghts, Weakness, Oppurtunities and Threats) yang disajikan dalam Gambar 4. Kegiatan yang kami tawarkan dimulai dari inventarisasi varietas padi 


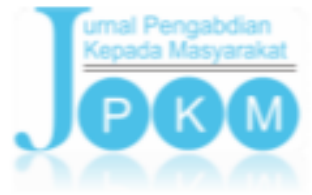

merah dan lembu spesifik lokal, penyuluhan, pengelolaan dan Pengendalian Hama Terpadu (PHT), Pelatihan teredukasi seperti: Pengaturan pola tanam padi merah, Pembuatan pupuk produktif, Pembuatan pestisida nabati, pemanfaatan keong mas menjadi pupuk tanaman, pembuatan pestisida nabati ramah lingkungan dan pendampingan petani.

Disamping itu perlu dilakukan inventarisasi dan pemetaaan keberadaan lokasi lembu lokal. Bantuan ternak jenis baru untuk penambahan populasi, peningkatan produksi dan komoditas, dan peningkatan bibit perlu ditumbuhkembangkan. Pelatihan Pembuatan probiotik, Pembuatan kompos tepat guna, Mendesain dan pelatihan inseminasi buatan lembu untuk menghasilkan susu segar dan daging yang Aman, Sehat, Utuh, dan Halal (ASUH) untuk dikonsumsi masyarakat yang ASUH. Sedangkan Pendidikan konservasi adalah upaya yang sangat vital untuk meningkatkan kesadaran generasi muda, petani, peternak dan masyarakat akan pentingnya menjaga sumber ketahanan pangan lokal dan nasional. Pengembangan usaha peternakan yang terintegrasi ditargetkan akan meningkatkan pendapatan demi kesejahteraan keluarga peternak.

Sinergi fungsi dan peran antara akademisi, petani, peternak, pihak terkait dan komunitas secara aktif dan interaktif dalam pembelajaran, berbagi pengalaman dan motivasi akan menumbuhkembangkan kesadaran petani dan peternak untuk meningkatkan kesadaran, peran aktif dan kemandirian masyarakat dalam bentuk ekonomi kreatif dalam meningkatkan taraf kehidupannya. Pentingnya berbagi pengalaman dan introduksi sains dan iptek kepada masyarakat/mitra Tani dan Peternak dalam pemanfataan bidang pertanian dan bidang peternakan sebagai pengelolaan dwi fungsi protein nabati dan protein hewani sebagai sumber pangan kehidupan masyarakat kita. Disamping itu, kami melakukan motivasi dan pelatihan edukasi dengan meningkatkan mutu produk beras merah yang diolah menjadi sumber makanan bergizi yang terjamin jumlah, mutu, penampilan dan kemasannya.

Sedangkan solusi yang berkaitan dengan produktivitas beras merah telah dilakukan sejak tahun 2008 hingga tahun 2027 seperti terlihat pada Gambar 5 dibawah ini. Pengabdian dilakukan fokus pada kajian padi beras putih dan padi merah di lahan dataran rendah, dataran tinggi, mangrove dan mengintegrasikan dengan mina padi. Kelangkaan bibit padi merah ditawarkan pemberdayaan masyarakat berupa kegiatan Focus Discussion Group (FDG), pengumpulan plasma nuftah (bank genetic), pembibitan, penanaman beras merah secara simultan, pelatihan pembuatan pupuk keong mas, pembuatan pestisida nabati, pembuatan pakan ternak dan pengelolaan lembu tepat guna. Selain itu program eduwisata dan pendidikan konservasi juga ditawarkan kepada pelajar sebagai generasi muda dan masyarakat.

\section{BAHAN DAN METODE}

\subsection{Rencana Kegiatan}

Kegiatan pengabdian PENGABDIAN MULTI

TAHUN 2020 ini dilaksanakan di Desa Tanjung Dolok, Kec,Marancar dan Desa Sijungkang,Kec, Angkola Timur dimulai Bulan Mei 2020 hingga November 2020. Motivasi yang kuat dari pihak mitra (petani dan peternak) untuk menghasilkan panen padi merah berkualitas serta lembu lokal unggul merupakan salah satu modal yang kuat. Untuk mendukung strategi pemecahan masalah mitra pada petani padi merah dan peternak lembu, adapun ipteks akan dilakukan meliputi 5 tahapan, yaitu:

\section{Tahap Persiapan}

Tahap awal dilakukan survei lokasi, inventarisasi permasalahan mitra, analisis masalah dan mencari solusi dengan pendekatan sain dan teknologi. Kemudian permasalahan tersebut dituangkan kedalam bentuk proposal pengabdian masyarakat yang diajukan kepada Menristek Dikti.

\section{Tahap Pelaksanaan}

Pada tahap pelaksanaan, tim PENGABDIAN MULTI TAHUN 2020 akan melakukan pembuatan pestisida nabati, pembuatan pupuk produktif keong mas, desain alat pencacah keong mas, alat pembuatan pakan ternak, kandang inseminasi buatan yang akan digunakan pada kegiatan pengabdian pada masyarakat. Alat tersebut akan diuji terlebih dahulu sebelum di mobilisasi ke lokasi pengabdian pada masyarakat. Setelah lolos dalam melakukan serangkaian uji yang dilakukan, maka alat pengolahan akan dimobilisasi ke lokasi pengabdian pada masyarakat.

\section{Tahap Pembimbingan}

Pada tahap pembimbingan, akan dilakukan langsung oleh tim PENGABDIAN MULTI TAHUN 2020 dibantu oleh beberapa orang mahasiswa yang dilaksanakan di lokasi PENGABDIAN MULTI TAHUN 2020.

\section{Pengendalian Hama Padi Dan Pengelolaan Lembu}

Penyuluhan dan demonstrasi pengendalian hama tanaman padi menggunakan pestisida nabati serta Focus Discussion Group (FDG) dilakukan pada kelompok petani padi merah dan peternak lembudan Pelatihan Pengendalian Hama Terpadu (PHT) akan disampaikan kepada mitra "Taberah, Tersapu, dan Terikmas".

\section{Penanganan Pascapanen Padi Dan Panen Ternak}

Kelompok Petani Padi Taberah dan Terikmas akan diberikan informasi mengenai pengolahan hasil pertanian, dan pelatihan penggunaan alat pencacah 


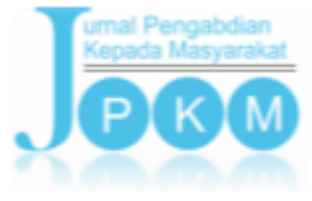

keong mas menghasilkan pupuk produktif. Sedangkan Kelompok Peternak Tersapu dan Terikmas akan diberi keterampilan membuat desain kandang dan inseminasi buatan pada lembu.

\subsection{Prosedur Kerja}

a. Bidang Pertanian Padi merah

Prosedur kerja kegiatan pengabdian masyarakat dimulai dari persiapan lahan, persiapan bahan dan alat, pembibitan padi merah, pembuatan pestisida nabati (pesnab), aplikasi pesnab, inventarisasio hama-penyakit padi, identifikasi hama dan analisis data.

Manakala rencana kegiatan pengabdian masyarakat pada petani padi meliputi hal berikut ini:

- Survei awal lahan yang akan digunakan dan perijinan melakukan pengabdian.

- Melakukan pelatihan bagi petani dalam memanfaatkan pestisida nabati pada tanaman padi.

- Melakukan pelatihan penggunaan alat pencacah keong mas.

- Pengumpulan data (karakteristik fisik, kimia, biologi, endofit).

- Pengumpulan data serangga dan hama padi.

- Identifikasi serangga dan hama di laboratorium.

- Analisis data.

- Penulisan dan penggandaan laporan.

- Seminar Nasional.

- Pembuatan buku ISBN.

- Publikasi jurnal internasional.

- Seminar hasil dan laporan akhir.

Pada Tahun Pertama Pengabdian dilakukan sejak tiga bulan pertama (Mei-Juni 2020) dilakukan persiapan lahan, persiapan bahan pestisida nabati, dan desain alat pencacah keong mas. Selanjutnya pada 4 (empat) bulan kegiatan pengabdian berikutnya (Juni-September 2020) dilakukan aplikasi pestisida nabati, demonstrasi pencacah keong mas, dan analisa data yang diperoleh dari petani padi meliputi inventarisasi serangga, hama dominan dan menghitung produktivitas beras yang dihasilkan. Kemudian dilakukan pembuatan buku ajar ber ISSBN dan seminar nasional dan internasional serta publikasi di jurnal terindek Scopus/Copernicus.

\section{b. Bidang Peternakan}

Kegiatan pengabdian dilakukan dalam beberapa tahapan yaitu:

Tahap I. Pembuatan Probiotik MOIYL

Bahan-Bahan :

1.Dedak halus $1 \mathrm{~kg}$

2.Gula merah/molases sebanyak $1 \mathrm{~kg}$

3.Tambahkan jerami padi cacah

4.Hijauan/daun kacang-kacangan

5.Pepaya, pisang atau nanas (blender dan saring airnya)

6.Starter Probiotik MOIYL 100-200 cc

7.Air bersih sebanyak 20 liter
8. Wadah ember

9.Jirigen 40 liter

Cara Membuat Probiotik

1.Semua bahan dicampurkan menjadi satu, tambahkan air dan diaduk hingga merata.

2.Masukan larutan yang telah homogen ke dalam wadah tertutup (jirigeni

3.Media disimpan di tempat yang gelap selama 7 hari mendukung proses fermentasi.

4.Pengamatan dilakukan setiap hari, jika dilihat jirigen mengembung maka keluarkan gas dengan membuka tutup secara perlahan, lalu ditutup rapat kembali.

Tahap II. Pembuatan Pakan Silase Limbah Tanaman

Bahan-Bahan:

1. Limbah jerami padi sebanyak $50 \mathrm{~kg}$

2. Molases 1L (2\%)

3. Bekatul $5 \mathrm{~kg}(10 \%)$

4. Probiotik MOIYL $50 \mathrm{ml}$

5. Air 5 liter.

Alat :

1.Drum silo tempat fermentasi.

2.Timbangan berdiri untuk menimbang jerami padi.

3.Ember besar dan kecil (wadah penampung)

4.Sendok, baskom, terpal.

5.Mesin/alat pencacah jerami.

6.Pisau, Plastik kg, blender.

7.Sarung tangan, masker.

8.Blender, saringan.

Cara membuat :

1.Siapkan larutkan molases dan probiotik MOIYL dengan air dan masukan ke dalam alat spray

2.Timbang semua bahan untuk silase

3.Hampar hijauan atau jerami di atas terpal/tikar plastik $20 \mathrm{~cm}$

4.Tabur bekatul diatas jerami secara merata

5.Siram dengan larutan molasses plus probiotik MOIYL

6.Tabur hijauan kembali dan siram kembali dengan larutan probiotik

7.Lakukan secara berlapis sampai bahan habis

8.Lakukan pengadukan/pencampuran semua bahan hingga homogeny (tercampur secara merata).

9.Bahan campuran diaduk rata kemudian dimasukkan kedalam drum (silo) sambil di padatkan agar tidak ada udara yang masuk.

10.Setelah bahan padat dan homogen, maka drum di tutup dengan katuppenutup rapat agar tidak ada udara yang masuk dan proses ensilase (pembuatan silase) secara an-aerob berjalan dengan baik.

\section{HASIL DAN PEMBAHASAN}

Aktivitas PENGABDIAN MULTI TAHUN 2020

di Desa Desa Tanjung Dolok, Kec,Marancar dan Desa 


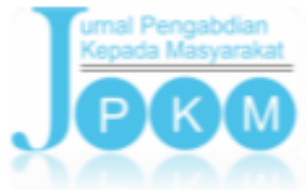

Sijungkang,Kec, Angkola Timur dimulai Bulan Mei 2020 hingga November 2020 berlangsung baik. Kegiatan awal dimulai dengan perkenalan anggota tim dengan kelompok tani dan ternak di DEsa Sijungkang, Tapsel (Gambar 1). Lalu dilakukan Sosialisasi dan Diskusi tentang permasalahan dalam menyediakan pakan ternak. Pelatihan dan Pendampingan kepada peternak lembu di Desa Sijungkang, Angkola Timur dihadiri poktan ternak, Bapak Abibun Siagian dan Bapak Amas Muda Ritonga.

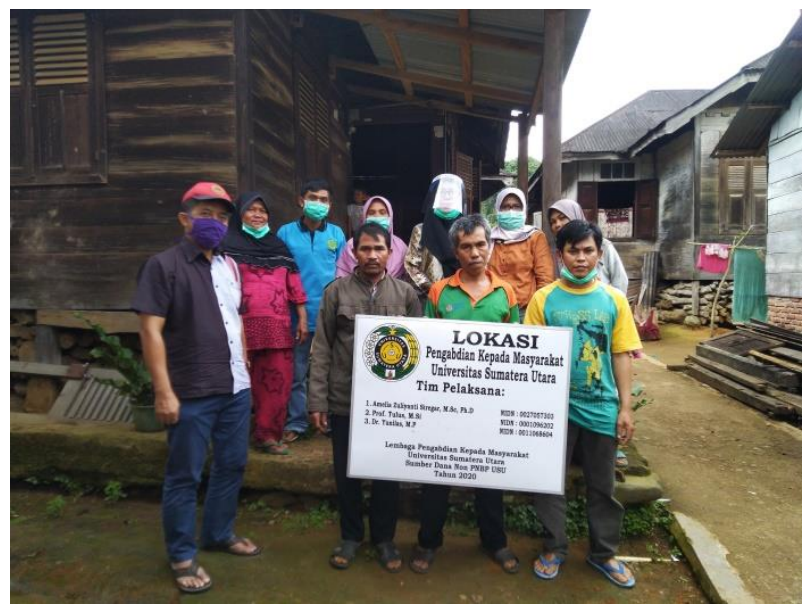

Gambar 1.Peternak di Desa Sijungkang, Tapsel, Sumut

Dari diskusi dan identifikasi dilapangan terdeteksi bahwa petani masih belum mengetahui bahwa penggunaan limbah sayuran dan buah-buahan data dijadikan sebagai bahan pembuatan pestisida nabati ramah lingkungan seperrti yang dijelaskan oleh pada Gambar 2 saat pelatihan pembuatan pestisida nabati ramah lingkungan yang dilakukan ibu Ameilia Zuliyanti Siregar, M.Sc, Ph.D sebagai koordinator Pemas Multi Tahun Non PNBP USU menyampaikan pengendalian hama terpadu tanaman padi dilakukan menggunakan perangkap lem warna kuning (Yellow Sticky Trap=YST), perangkap jaring (Sweep net) dan pembuatan pestisida nabati ramah lingkungan dari bawang putih, daun pepaya dan cabe merah melalui sesi pelatihan,

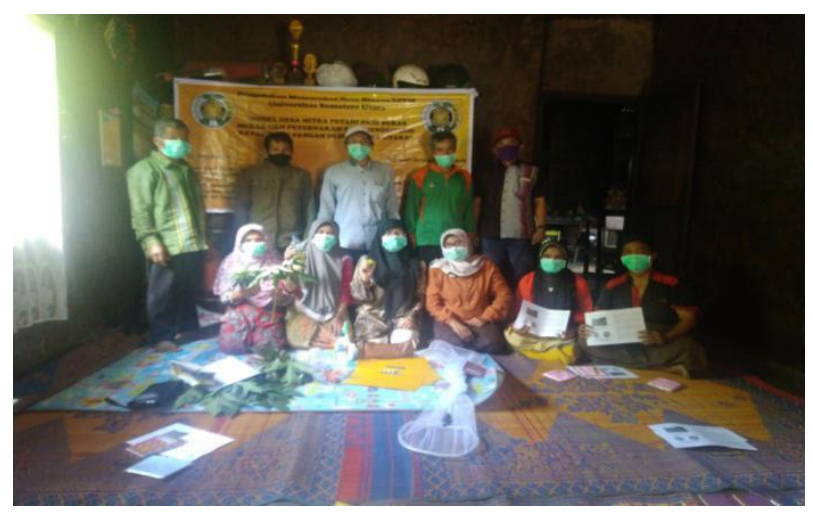

Gambar 2. Petani beras merah di Desa Tanjung Dolok Tapsel

Selanjutnya, pestisida nabati dari bawang putih, daun pepaya dan cabe merah yang dihasilkan langsung diaplikasikan dilahan padi sawah oleh Petani, Bapak M. Yakub Hasibuan dan Bapak Adenan Pasaribu. sebagaimana dideskripsikan pada Gambar 3 dibawah ini. Tercatat beberapa hama padi, seperti Sogatella sp, O.oryzae, dan N.lugens mati pada daun padi.

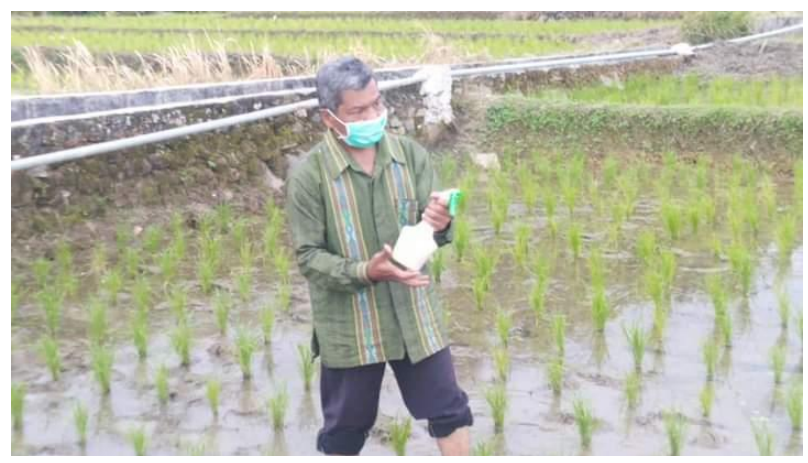

Gambar 3. Aplikasi petisida nabati ke tanaman padi merah Selanjutnya, dosen peternakan FP USU, Ir Yunilas, M.P menyampaikan prosedur pembuatan Pakan Silase, campuran jerami padi $50 \mathrm{~kg}$, bekatul $5 \mathrm{~kg}$, Molases 1L (2\%), Probiotik MOIYL $50 \mathrm{ml}$ serta air 10 liter. Manakala pembuatan pupuk organik cair terdiri dari molasses $10 \%$, sisa sayuran dan buah-buahan sebanyak 30\%, dan air sebanyak $60 \%$ yang dideskripsikan pada Gambar 4 dibawah ini.

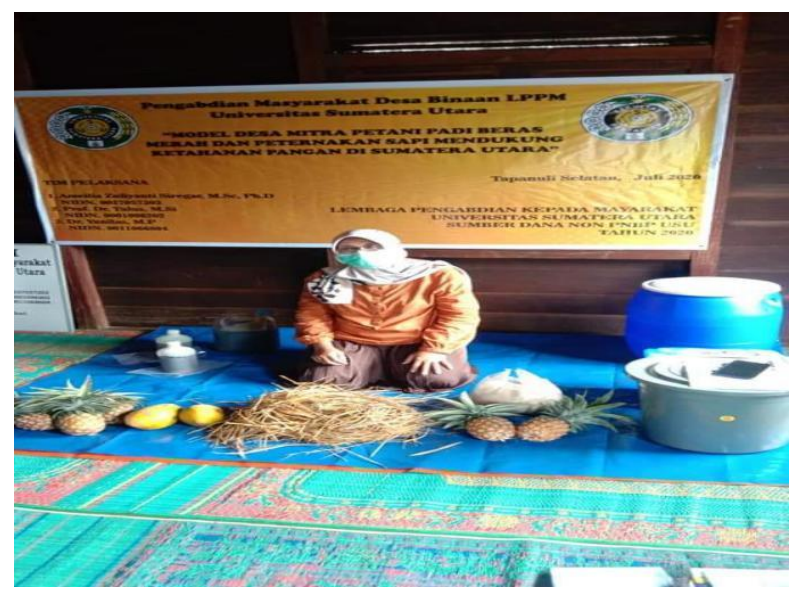

Gambar 4.Pelatihan Pembuatan Pakan Ternak Prebiotik

Sumber pakan ternak lembu yang disosialisasikan berupa silase limbah tanaman serta pupuk organik cair dapat dilakukan petani, peternak dan masyarakat Tapsel sebab bahan limbah mudah didapat, murah dan tepat guna menghasilkan bibit siap tanam selama sebulan setelah difermentasi. 


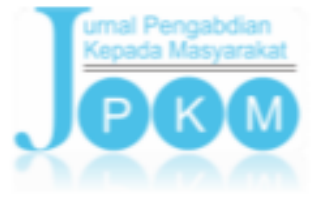

Ketua LPPM USU, Prof Tulus menyampaikan bahwa permasalahan yang diidentifikasi pada mitra, meliputi: "Sumber pakan hijau terbatas, adanya sekam padi, jerami, limbah sayuran, limbah buah-buahan di Desa Marancar dan Desa Sijungkang, Angkola Timur. Sebagai sumber alternatif pakan untuk mengubah pandangan petani bahwa pakan ternak tidak harus hijau, terpenting mengandung Karbohidrat, Serat, Protein, Vitamin dan Mineral".

\section{Kesimpulan}

Penggunaan Yellow Sticky Trap (perangkat pelikat kuning), pemakaian Sweep Net (perangkap jarring, aplikasi pestisida nabati (daun pepaya cabe merah,bawang putih) dalam Pengendalian Hama Terpadu padi merah sangat efektif. Manakala pelatihan pembuatan prebiotik pakan ternak sangat bermanfaat bagi peternak di Tapsel. Metode program pengabdian dilakukan kompilasi, menggunakan survey, sosialisasi, pelatihan, Focus Discussion Group (FDG), dan Pendampingan Tim Pengabdian Multi Tahun Non PNBP LPPM USU, diprediksikan dapat mendukung kesejahteraan petani-peternak mendukung ketahanan pangan di Tapsel.

\section{Ucapan Terima Kasih}

Ucapan terimakasih yang tulus disampaikan kepadi petani padi merah dan masyarakat di Desa Tanjung Dolok, Marancar dan peternak di Desa Sijungkang, Angkola Timur. Penghargaan setinggitingginya kepada Rektor USU dan LPPM USU yang memfasilitasi pendanaan Skim Program Skim Multi Tahun Non PNBP USU dengan Nomor 288/UN5.2.3.2.1/PPM/2020.

\section{Daftar Pustaka}

Afza H. (2016). Peran Konservasi Dan Karakterisasi Plasma Nutfah Padi merah Dalam Pemuliaan Tanaman. Balai Besar Pengabdian dan Pengembangan Bioteknologi dan Sumberdaya Genetik Pertanian. Jurnal Litbang Pertanian, 35 (3), 23-29.

Badan Penelitian dan Pengembangan Pertanian. Departemen Pertanian. Jakarta. (2018). Pertanian Dalam Angka. Jakarta.

BB Biogen (Balai Besar Pengabdian dan Pengembangan Bioteknologi dan Sumberdaya Genetik Pertanian). (2015). Bank Plasma Nutfah, httpp://biogen.litbang.pertanian.go.id/index.php/pr ofil/fasilitas/bank-plasma-nutfah/. Diakses pada tanggal 10 Agustus 2020.

Direktorak Jenderal Bina Produksi Peternakan. (2002). Pengembangan Kawasan Agribisnis Berbisnis Berbasis Peternakan.

FAO (Food and Agriculture Organization). (2014). Genebank Standradsfot Plant Genetic Resources for Food and Agriculture. Rev.ed. FAO, Rome.

Hayanto. B., I. Inounu., Arsana. B \& K. Diwyanto. (2002). Sistem Integrasi Padi-Ternak. Penerbit Swadaya, Jakarta..

Ilham N., K. Kariyasa, B. Wiryono, M. N. A. Kriom, dan Hastuti, S. (2001). Analisis Penawaran dan Permintaan Komoditas Peternakan Unggulan. Pusat Pengabdian dan Pengembangan Sosial Ekonomi Pertanian. Bogor.

Juniawati, S. Usmiyati, \& Damayanthi, E. (2015). Pengembangan keju rendah lemak sebagai pangan fungsional. J.LitbangPet., 34[1]. 31-40.

John A. S. (2018). Sumut Kirimkan 5 Jenis Padi Lokal untuk Diteliti. Harian Medan Bisnis. Medan. Diakses pada tanggal 19 Agustus 2020.

Kadir, T.S., I. Hanarida, D.W. Utami, S. Koerniati, A.D. Ambarwati, A. Apriana, \& Sisharmini, S. (2007). Evaluasi ketahanan populasi haploid ganda silangan IR64 dan Oryza rufipogon terhadap hawar dan bakteri pada stadia bibit. Bul. Plasma Nutfah $10,28-32$.

Kariyasa, K. (2003). Keterkaitan Pasar Jagung, Pakan dan Daging Ayam Ras di Indonesia. Thesis Magister Sains. Sekolah Pascasarjana, Institut Pertanian Bogor, Bogor.

Khan, M.H., Z.A. Dar and Dar, S.A. (2015). Breeding strategies for imptoving rice yield. AReview. AGrric.Sci.6, 467-478.

Manzi, P., S. Marconi and Pizzoferrato, L. (2007). New functional milk-based products in the Italian market. J. Food Chem, 104, 808-813.

Muzani A, Y. Geli Bulu, K. Puspadi dan Panjaitan, T.S. (2004). Potensi Pakan Dalam Sistem Integrasi Tanaman Ternak di Lombok NTB. Pros. Lokakarya Sistem dan Kelembagaan Usahatani 
Tanaman Ternak. Badan Litbang Pertanian, Jakarta.

Nurhayati, A. Jamil, R. F. Zona, Jakoni, A. S. Alim, Elfiani, dan Empersi. (2012). Buku Rekomendasi Pemupukan Padi Sawah pada 9 (sembilan) Kabupaten Lokasi Program OPRM di Provinsi Riau. BPTP Riau.

Riyanto. (2004). Pola Distribusi Populasi Keong Mas (Pomacea canaliculata L.) Di Kecamatan Belitang Oku. Majalah Sriwijaya, 37 (1), 70-75.
Riani, E. (2011). Kemampuan reproduksi keong emas (Pomacea sp.) daging kuning dan daging hitam. Jurnal Molusca Indonesia, 2(1), 9-13.

Suriadikarta, D. A., dan Sutriadi, M. T.. (2007). Jenisjenis lahan berpotensi untuk pengembangan pertanian di lahan rawa. J. Pengabdian \& Pengembangan Pertanian, 26(3), 115-122.

Tripp R, van der Heide, W. (1996). The Erosion of crop genetic diversity: Challenges, strategies and uncertainties. Overseas Development Institute. 